\title{
Elemental Concentration of commonly used Clay Potteries from some selected locations in Niger State of Nigeria using Instrumental Neutron Activation Analysis
}

\author{
R. L. Njinga ${ }^{1 *}$ U.U. Elele ${ }^{2}$ and I.O.B. Ewa ${ }^{3}$ \\ ${ }^{I^{*}}$ Department of Physics, Ibrahim Badamasi Babangida University, Lapai, Niger State, Nigeria \\ ${ }^{2}$ Department of Chemistry, Ibrahim Badamasi Babangida University, Lapai, Niger State, Nigeria \\ ${ }^{3}$ Centre for Energy Research and Training, Ahmadu Bello University, Zaria
}

\begin{abstract}
We appraised in this study the public awareness of the imminent danger due to elemental concentration of the resident in Lapai local government areas and Tatiko, a village under Paikoro local government areas in Niger State, Nigeria about the constant usage of clay potteries in cooking, storage of drinking water, eating and drinking of water. Instrumental Neutron Activation Analysis (INAA) was employed and two irradiation regimes developed based on short lived and long lived radionuclides. The Nigerian Research Reactor-1 was employed and the irradiation time set to five minutes and six hours at operating fluxes of $2.5 \times 10^{11} \mathrm{n} / \mathrm{cm}^{2} / \mathrm{sec}$ and $5.0 \times 10^{11} \mathrm{n} / \mathrm{cm}^{2} / \mathrm{sec}$ respectively for the two regimes developed. The gamma-rays from the activated samples were measured using the HPGe detector and twenty four elements; $\mathrm{Na}, \mathrm{Mg}, \mathrm{Al}, \mathrm{Ti}, \mathrm{V}$, $K, \mathrm{Mn}, \mathrm{Dy}, \mathrm{Cr}, \mathrm{Fe}, \mathrm{As}, \mathrm{Br}, \mathrm{La}, \mathrm{Sm}, \mathrm{Yb}, \mathrm{Sc}, \mathrm{Co}, \mathrm{Rb}, \mathrm{Cs}, \mathrm{Ba}, \mathrm{Eu}, \mathrm{Lu}, \mathrm{Hf}$, Ta were obtained quantitatively. Arsenic (As) and chromium (Cr) known to be heavy metals fall in the range of $0.6450 \pm 0.16 \mathrm{ppm}-1.6350 \pm 0.06 \mathrm{ppm}$ and $29.2050 \pm 0.36 \mathrm{ppm}-74.8050 \pm 0.23$ ppm respectively. The concentrations of La, Sm, Co, Ba, and Cr also known to be toxic were obtained within the range of $56.20 \pm 21-102.00 \pm 43 \mathrm{ppm}, 8.14 \pm 0.32-13.10 \pm 0.2$ ppm, $6.22 \pm 0.22-21.50 \pm 0.26 \mathrm{ppm}, 218.00 \pm 28-711.00 \pm 41 \mathrm{ppm}$ and $29.20 \pm 23-80.80 \pm 21 \mathrm{ppm}$ respectively in all the ten composite clay potteries samples. Furthermore the concentrations of Al and Ti in the samples were obtained at percentage levels in the range of $7.605 \pm 0.006 \%-10.0350 \pm 0.026 \%$ and $0.40 \pm$ $0.03 \%-1.02 \pm 0.07 \%$ respectively. These detected metals may dissolve from the clay potteries onto the food during cooking, eating, drinking of water or storage of food/water and will result to serious health consequence. Keywords: Toxic Elements, Research Reactor, Clay Potteries, Heavy Metal, Light Metals,
\end{abstract}

\section{Introduction}

The Instrumental Neutron Activation Analysis (INAA) method is known to be sufficiently sensitive for the determination of elemental concentrations down to parts per million (ppm) and part per billion (ppb). The technique is sufficiently known to be non-destructive (Funtua et al., 2012) and has led to some important features or relationships between the trace elemental pattern and the condition of the clay formation (Lee and Kwun 1985). However, the pre-processing of clay potteries involves the removal of the coarse material embedded in the clay potteries and to prevent the clay from cracking when fired. In 1974, Tobia and Sayre carried out NAA on some Egyptian clays/shales and subdivided the Nile flood Plain material into three broad layers which were deposited in the Holocene, the Pleistocene and the Pliocene. They found some significant chemical differences between the shales or the clays in term of geological formation and noted some chemical similarities between the shales and the clays of the same formation.

In the past, most studies involving INAA of ceramics have been focused on elements producing longlived isotopes (Perlman and Asaro 1970; 1971, Brooks et al., 1974 and Kaplan et al., 1982). The evaluation of some elements producing short-lived isotopes such as; $\mathrm{U}, \mathrm{Dy}, \mathrm{Ba}, \mathrm{Ti}, \mathrm{Mg}, \mathrm{Na}, \mathrm{V}, \mathrm{Al}, \mathrm{Mn}, \mathrm{Cl}$ and $\mathrm{Ca}$ with varying analytical precisions were carried out in University of Toronto (Kay et al., 1973).

The term trace metals have been variously referred to as common pollutants, which are widely distributed in the environment with source mainly from the weathering of minerals and soil. However, trace metals are define as those metallic elements, low in the periodic table with high atomic number (weight) $>100$, or a relative density greater than five (Gharib, 2004). Some traces metals such as $\mathrm{Cu}, \mathrm{Cd}, \mathrm{Zn}, \mathrm{Mn}, \mathrm{Ni}$, and V may be important in the nutrition of plant and animals or humans while others like $\mathrm{Pd}, \mathrm{Cd}$, and $\mathrm{Hg}$ are known to possess virtually negative nutritional effect (Bauer, 1999; Carlisle, 1986; Hurley et al., 1987; Greger, 1989 and Njinga et al., 2011a. All these trace metals over long term duration may cause gradual damage of the organisms or cells/organs (Muir, 1997; Ames et al., 2002 and Ewa et al., 2000).

Heavy metals normally occurring in nature are not harmful to the environment since they are only present in small amounts. The heavy metals become toxic or posed danger when they showed up in huge amounts primarily due to industrialization or other anthropogenic activities. Some of these heavy metals that are 
detrimental to human health includes; $\mathrm{Hg}, \mathrm{As}, \mathrm{Cu}, \mathrm{Pb}$, and $\mathrm{Zn}$ (Anderson and Jensen, 1993; Casdorph, 2001; Oladipo et al., 2011; Ahlrich, 1972; Menaut et al., 1985 and Ewa et al., 2000).

The inhabitants of Lapai Local Government Area (LLGA) and Tatiko a village under Paikoro Local Government Area (PLGA) of Niger State in Nigeria used clay potteries products exclusively for drinking and storage of water, cooking of food and herbs. Majority of the local pregnant women and little children eat the black or red clay directly from the host clay deposits. Hence, the objectives of this work include; investigating the elemental concentrations using INAA of some of these clay potteries. The elements obtained would be classified and analyzed in the following categories; heavy metals, trace metal, essential and toxic metals, possibly required elements and required elements. In achieving the set objectives, a protocol based on two irradiation schemes; for short lived radionuclides and long lived radionuclides in clay potteries sample (or archaeological samples) would be developed.

To reach the aforementioned objectives, a set of about 92 samples were transformed to ten composites samples (Table 1.0) and analyzed by INAA. Special cares were taken in the research to maintain quality control of the analytical results, which were produced in duplicate for every sample, and for repeated analysis of the standard reference material (SRM) of the National Institute of Standard and Technology (NIST), 2009 San Joaquin Soil specifically coal fly ash $1633 \mathrm{~b}$.

Table 1.0: The samples analyzed for the determination of radionuclides and concentrations.

\begin{tabular}{|c|c|c|c|}
\hline Sample Code & Sample Type & Number of samples & Composite samples collections \\
\hline LAP-Red & Lapai-red clay & $\begin{array}{l}\text { Composite of } 8 \\
\text { different samples of } \\
\text { same environment }\end{array}$ & $\begin{array}{l}\text { Each red clay samples were collected from eight subsamples } \\
\text { in an area of approximately } 1 \mathrm{~m}^{2} \text { and up to a typical depth of } \\
\text { about } 20 \mathrm{~cm} \text { from the top surface layer and mixed } \\
\text { thoroughly to make a composite sample. }\end{array}$ \\
\hline LAP-Black & Lapai-black clay & $\begin{array}{l}\text { Composite of } 8 \\
\text { different samples of } \\
\text { same environment }\end{array}$ & $\begin{array}{l}\text { Each black clay samples were collected from eight } \\
\text { subsamples in an area of approximately } 1 \mathrm{~m}^{2} \text { and up to a } \\
\text { typical depth of about } 20 \mathrm{~cm} \text { from the top surface layer and } \\
\text { mixed thoroughly to make a composite sample. }\end{array}$ \\
\hline TAT-Black & Tatiko-black clay & $\begin{array}{l}\text { Composite of } 8 \\
\text { different samples of } \\
\text { same environment }\end{array}$ & $\begin{array}{l}\text { Each black clay samples were collected from eight } \\
\text { subsamples in an area of approximately } 1 \mathrm{~m}^{2} \text { and up to a } \\
\text { typical depth of about } 20 \mathrm{~cm} \text { from the top surface layer and } \\
\text { mixed thoroughly to make a composite sample. }\end{array}$ \\
\hline TAT-Red & Tatiko-red clay & $\begin{array}{l}\text { Composite of } 8 \\
\text { different samples of } \\
\text { same environment }\end{array}$ & $\begin{array}{l}\text { Each red clay samples were collected from eight subsamples } \\
\text { in an area of approximately } 1 \mathrm{~m}^{2} \text { and up to a typical depth of } \\
\text { about } 20 \mathrm{~cm} \text { from the top surface layer and mixed } \\
\text { thoroughly to make a composite sample. }\end{array}$ \\
\hline ppTAT-Ceramics & $\begin{array}{l}\text { Plain-part of } \\
\text { Tatiko ceramics }\end{array}$ & $\begin{array}{l}\text { Composite of } 12 \\
\text { different parts from } 4 \\
\text { ceramics }\end{array}$ & $\begin{array}{l}\text { Twelve different plain parts from four ceramics from Tatiko } \\
\text { were mixed thoroughly to make a composite sample. }\end{array}$ \\
\hline TAT-Clay & $\begin{array}{l}\text { Tatiko-clay } \\
\text { deposit }\end{array}$ & $\begin{array}{l}\text { Composite of } 8 \\
\text { different samples of } \\
\text { same environment }\end{array}$ & $\begin{array}{l}\text { Each Tatiko clay deposits were collected from eight } \\
\text { subsamples in an area of approximately } 1 \mathrm{~m}^{2} \text { and up to a } \\
\text { typical depth of about } 20 \mathrm{~cm} \text { from the top surface layer and } \\
\text { mixed thoroughly to make a composite sample. }\end{array}$ \\
\hline dTAT-Ceramics & $\begin{array}{l}\text { Designed part of } \\
\text { Tatiko ceramics }\end{array}$ & $\begin{array}{l}\text { Composite of } 12 \\
\text { different designed parts } \\
\text { from } 4 \text { ceramics }\end{array}$ & $\begin{array}{l}\text { Twelve different parts from four different ceramics mixed } \\
\text { clay were mixed thoroughly to make a composite sample. }\end{array}$ \\
\hline bTAT-Bent & $\begin{array}{l}\text { Bentonite of } \\
\text { Tatiko-clay }\end{array}$ & $\begin{array}{l}\text { Composite of } 8 \\
\text { different samples of } \\
\text { same environment }\end{array}$ & $\begin{array}{l}\text { Each Tatiko bentonite clay samples were collected from } \\
\text { eight subsamples in an area of approximately } 1 \mathrm{~m}^{2} \text { and up to } \\
\text { a typical depth of about } 20 \mathrm{~cm} \text { from the top surface layer and } \\
\text { mixed thoroughly to make a composite sample. }\end{array}$ \\
\hline mTAT-Pot & $\begin{array}{l}\text { Tatiko finished } \\
\text { product of the } \\
\text { mixed clay }\end{array}$ & $\begin{array}{l}\text { Composite of } 12 \\
\text { different parts from } 4 \\
\text { finished mixed clay }\end{array}$ & $\begin{array}{l}\text { Twelve different parts from four finished mixed clay were } \\
\text { mixed thoroughly to make a composite sample. }\end{array}$ \\
\hline b/rTAT-clay & $\begin{array}{l}\text { Mixture of Tatiko } \\
\text { black and red } \\
\text { clay }\end{array}$ & $\begin{array}{l}\text { Composite of } 8 \\
\text { different mixture of } \\
\text { black and red clay }\end{array}$ & $\begin{array}{l}\text { Each black and red clay from Tatiko were collected from } \\
\text { eight subsamples in an area of approximately } 1 \mathrm{~m}^{2} \text { and up to } \\
\text { a typical depth of about } 20 \mathrm{~cm} \text { from the top surface layer and } \\
\text { mixed thoroughly to make a composite sample. }\end{array}$ \\
\hline
\end{tabular}

\subsection{Geology of Niger State and Study Locations}

Niger State, like other states on the same latitude, is covered by two major rock formations the sedimentary rocks to the south, characterized by sandstones and alluvial deposits, particularly along the Niger valley and in most parts of Borgu, Bida, Agaie, part of Lapai, Mokwa, Lavun, Gbako and Wushishi LGAs. This subarea also contains the extensive flood plains of the River Niger and this has made the State to be one of the largest and most fertile agricultural lands in the country.

To the north is the basement complex, characterized by granitic outcrops or iselbergs which can be found in the vast topography of roling landscape. Such iselbergs dominate the landscape in Rati, Shiroro, Minna, Mariga, Gurara and some part of Lapai. Three major soils types can be found in the State. These include the ferruginous tropical soils, hydromorphic soils and ferrosols. The most predominant soil type is the ferruginous 
tropical soils which are basically derived from the Basement Complex rocks, as well as from old sedimentary rocks.

The State experiences two distinct seasons the dry and wet seasons. The annual rainfall varies from about $1,600 \mathrm{~mm}$ in the south to $1,200 \mathrm{~mm}$ in the north. The duration of the rainy seasons ranges from 150 to 210 days or more from the north to the south.

Tatiko is a village in the North central part of Nigeria which is located in Paikoro local government area in Niger State of coordinate's $9^{\circ} 26^{\prime} \mathrm{N} 6^{\circ} 38^{\prime} \mathrm{E} / 9.433^{\circ} \mathrm{N} 6.633^{\circ} \mathrm{E}$. Lapai is a local government area in Niger State, adjoining the Federal Capital Territory. It has an area of $3,051 \mathrm{~km}^{2}$ and a population of 110,127 at the 2006 census. The area is roughly coterminous with the Lapai Emirate. Lapai is located at latitude $9^{\circ} 03^{\prime} 00^{\prime \prime} \mathrm{N}$ and longitude $6^{\circ} 34^{\prime} 00^{\prime \prime} \mathrm{E}$. These two locations are covered all over with clay minerals that were formed over long periods of time due to gradual chemical weathering of rocks and low concentrations of carbonic acid including other diluted solvents (Oladipo et al., 2012). The clays formation in these selected location exhibit similar characteristic of plasticity when mixed with water in certain proportions and when dried or fired in a kiln, they become firm with permanent physical structures (Mosugu et al., 1999).

\subsection{Theory of Neutron Activation Analysis}

The sensitivity of the method has been described in several places with the recent review being that of (Tolgyessy and Klehr, 1987) and can be considered to be about ppb level for reactor irradiations. The sensitivity is a function of nuclear parameters of the element in question: neutron cross section, isotope abundance, halflife, gamma-ray abundance, available neutron flux, length of irradiation, detector efficiency, matrix composition, and the total sample size. NAA has a lead over other methods because of the possibility of simultaneous assaying of a majority of elements in representative mass of substance with considerable sensitivity as compared to other conventional techniques which require special sample preparation procedures before analysis (Abugassa et al., 2004).

In instrumental neutron activation analysis, decomposition and radiochemical separation of the radioactive sample are not necessary (De Soete et al., 1972). The radionuclides are determined nondestructively on the basis of the differences in their decay rates through measurements at different decay intervals by means of high-resolution detectors. The desired elements are achieved by optimizing irradiation parameters like; energy, rate of the neutrons, irradiation time, and decay and counting times.

The NAA technique that was employed in this work in determining the elemental concentration in the analyzed samples were calculated based on irradiating the samples and some standard samples containing a known amount of the element of interest together. If the analyzed sample and the standard are both measured on the same detector and the decay and irradiation times between the two are corrected, the mass of the element in the analyzed sample will be calculated using the half-life of the measured isotope based on the equation:

$$
\begin{aligned}
\frac{\mathrm{A}_{\mathrm{AN}}}{\mathrm{A}_{S T D}}= & \frac{m_{\mathrm{AN}}}{m_{S T D}} \frac{\left(e^{-\lambda T_{D}}\right)_{\mathrm{AN}}}{\left(e^{-\lambda T_{D}}\right)_{S T D}} \\
& \text { where } \mathrm{A}_{\mathrm{AN}} \text { and } \mathrm{A}_{S T D} \text { are induced activity of the analyzed and standard samples, } m_{\mathrm{AN}} \text { and } m_{\mathrm{STD}} \text { are }
\end{aligned}
$$
the masses of the analyzed and standard elements, $\lambda$ is decay constant for the isotope, and $T_{\mathrm{D}}$ is decay time.

Since the reactor flux is relatively stable (Njinga et al., 2012), when performing short irradiations, the irradiation time, decay, and counting times were normally fixed for all the analyzed samples and standards such that the time dependent factors canceled out. Thus we simplified Equ. (1) as:

$$
\mathrm{C}_{\mathrm{AN}}=\mathrm{C}_{\mathrm{STD}} \frac{\mathrm{W}_{\mathrm{AN}}}{\mathrm{W}_{\mathrm{STD}}} \frac{\mathrm{A}_{\mathrm{AN}}}{\mathrm{A}_{\mathrm{STD}}},
$$

where $C$ is concentration of the element and $W$ is weight of the sample and standard.

With respect to the time of measurement, NAA falls into two categories: prompt gamma-ray neutron activation analysis (PGNAA), where measurements take place during irradiation, and delayed gamma-ray neutron activation analysis (DGNAA), where the measurements follow radioactive decay. The DGNAA is more common in most NAA labouratories because of the delayed gamma rays which are always measured and about $70 \%$ of the elements have this suitable property (Ahmed et al., 2006 and Njinga et al., 2012).

The induced activity due to neutron bombardment of the clay potteries samples from some selected locations in Lapai and Tatiko LGAs in Niger State of Nigeria after irradiation with the miniature research reactor is;

$$
A=\varepsilon I_{\lambda} N \sigma \varphi\left(1-e^{-\lambda t_{i}}\right) e^{-\lambda t_{d}},
$$


where $N$ is number of target atoms, $\sigma$ is cross section, $\varphi$ is flux parameter, $t_{i}$ is irradiation time, and $\lambda$ is decay constant. The term $\left(1-e^{-\lambda t_{i}}\right)$ is called the saturation faction, $\varepsilon$ is efficiency of the detector used and $I_{\gamma}$ is absolute gamma ray abundance.

\section{Sample Preparation}

The samples were dried with the infrared lamp at a temperature of $40{ }^{\circ} \mathrm{C}$ to $60{ }^{\circ} \mathrm{C}$ for 24 hours. Thereafter, crushed one after the other and little quantity of the samples were taking for weighing using analytical balance called Mettlar EA 240 and the weight of the samples recorded for further calculations. Each sample was then wrapped up with polythene bags with the aid of an air blower for sealing and were then put into a vial and sealed, ready for irradiation.

\subsection{Irradiation and Counting Schemes}

Typically two irradiation schemes were performed using Nigeria Research Reactor-1 (NIRR-1) facility for determination of short-lived and long-lived radionuclides. For the short lived radionuclides, the sample weights were $150 \mathrm{mg}-250 \mathrm{mg}$ and the irradiation time (together with the SRM) were set to 5 minutes at a neutron flux setting of $2.5 \times 10^{11} \mathrm{n} / \mathrm{cm} 2 / \mathrm{sec}$ in the outer channel (B4) which is away from the reactor core and the radionuclides of interest are shown in Table 2 and 3. For all the samples, decay periods of about 5 minutes were needed depending on the induced activities present in the sample to be analyzed. Counting period of 10 minutes were adopted to determined the concentration of the identified elements.

For the short-lived radionuclides, the $\gamma$-ray counting was done in two separate ways namely; first short counting, and second short counting. The first short lived counting was done instantly after the sample irradiation for exactly 10 minutes while the second short counting was done after 3 to 4 hours of sample irradiation for 30 minutes.

Table 2: Properties of short lived radionuclide in the first counting

\begin{tabular}{clll}
\hline Elements & Radionuclide & Half-life $\left(\mathrm{m}^{*}\right)$ & $\gamma$-ray energies $(\mathrm{keV})$ \\
\hline $\mathrm{Mg}$ & ${ }^{27} \mathrm{Mg}$ & 9.46 & 843.8 \\
$\mathrm{Al}$ & ${ }^{28} \mathrm{Al}$ & 2.24 & 1779.0 \\
$\mathrm{Ca}$ & ${ }^{49} \mathrm{Ca}$ & 8.72 & 3084.5 \\
$\mathrm{Ti}$ & ${ }^{51} \mathrm{Ti}$ & 5.76 & 320.1 \\
$\mathrm{~V}$ & ${ }^{52} \mathrm{~V}$ & 3.75 & 1434.1 \\
\hline
\end{tabular}

Table 3: Properties of short lived radionuclide in the second counting

\begin{tabular}{llll}
\hline Elements & Radionuclide & Half-life & $\gamma$-ray energies $(\mathrm{keV})$ \\
\hline $\mathrm{Na}$ & ${ }^{24} \mathrm{Na}$ & $14.96 \mathrm{~h}$ & $1368.6,2754.0$ \\
$\mathrm{Mn}$ & ${ }^{56} \mathrm{Mn}$ & $2.580 \mathrm{~h}$ & $846.8,1810.7,2113.1$ \\
$\mathrm{Eu}$ & ${ }^{152} \mathrm{Eu}$ & $13.33 \mathrm{y}$ & 841.6 \\
$\mathrm{Dy}$ & ${ }^{165} \mathrm{Dy}$ & $2.33 \mathrm{~h}$ & 94.7 \\
\hline
\end{tabular}

(Courtesy, CERT, ABU, Zaria)

For long half-lives radionuclides, the samples with the weights of $150 \mathrm{mg}-250 \mathrm{mg}$, together with the SRM, were irradiated for six hours in the inner channel (B2), which is close to the core of the nuclear research reactor at a neutron flux setting of $5.0 \times 10^{11} \mathrm{n} / \mathrm{cm} 2 / \mathrm{sec}$. After irradiation, the samples and standard were ejected from the reactor via the pneumatic transfer system and allowed to decay to an appropriate dead time. In the case of the long irradiated samples, two protocols were established in order to obtain any of the following elements: As, Br, La, Sm, Yb, U, Sc, Cr, Fe, Co, Zn, Se, Rb, Cs, Ba, Eu, Lu, Hf, Ta, Sb, and Tb.

The first stages of counting were done after 4 to 5 days of decay, and both types of samples (SRM and all the other samples) counted for 10 minutes.

The second stage of the counting was performed after nine days for each type, that is, SRM, and all the other samples counted for sixty minutes. The properties of some of the long-lived radionuclides are presented in Table 4.

All the above-mentioned counting procedures for the samples as shown in Table 1.0 were carried out in a separate set-up with the gamma-ray HPGe detector and Pd-shielded to ensure safety of the analyst and the associated electronic components. The gamma-rays from the samples were measured using the HPGe detector.

The multipurpose gamma ray analysis software WINSPAN 2004 (Liyu, 2004) version was used for the peak identification, spectra analysis, and quantification of the elements present. The detector was calibrated in energy certified radioactive sources: Cs-137 emitting gamma-ray energy of $662 \mathrm{keV}$ and Co-60 emitting two gamma-rays at 1172 and $1332.5 \mathrm{keV}$. The efficiency curve for the gamma-ray high purity germanium (HPGe) detector (ORTEC), model number "GEM-30195," has been developed and published (Njinga et al., 2011b). 
Table 4: Properties of long-lived radionuclide in the first counting

\begin{tabular}{llll}
\hline Elements & Radionuclide & Half-life & $\gamma$-ray energies $(\mathrm{keV})$ \\
\cline { 2 - 2 } & ${ }^{24} \mathrm{Na}$ & $14.96 \mathrm{~h}$ & $1368.6,2754.0$ \\
$\mathrm{Na}$ & ${ }^{42} \mathrm{~K}$ & $12.36 \mathrm{~h}$ & 1524.6 \\
$\mathrm{As}$ & ${ }^{76} \mathrm{As}$ & $26.32 \mathrm{~h}$ & 559.1 \\
$\mathrm{Br}$ & ${ }^{82} \mathrm{Br}$ & $35.30 \mathrm{~h}$ & $776.50,554.30$ \\
$\mathrm{La}$ & ${ }^{140} \mathrm{La}$ & $40.27 \mathrm{~h}$ & $487.0,1596.2$ \\
$\mathrm{Sm}$ & ${ }^{153} \mathrm{Sm}$ & $46.27 \mathrm{~h}$ & 103.20 \\
$\mathrm{~Np}(\mathrm{U})$ & ${ }^{239} \mathrm{U}$ & $56.64 \mathrm{~h}$ & 277.60 \\
$\mathrm{Yb}$ & ${ }^{175} \mathrm{Yb}$ & $4.190 \mathrm{~d}$ & 396.30 \\
\hline
\end{tabular}

(Courtesy, CERT, ABU, Zaria)

\subsection{Interference in Results}

Interference can occur when different component sample elements produce similar gamma rays or by counting only after the shorter-lived nuclide had decayed. Other interference can occur if another type of nuclear reaction concurrently produces the radionuclide of interest. A $\gamma$-ray spectral interference occur when two radionuclides emit $\gamma$-rays of the same, or nearly the same energy. These problems were solved by using high resolution germanium detector, choosing suitable decay and counting times. It is often wrongly assumed that NAA methods are completely independent of matrix. The presence of high $\mathrm{Z}$ elements, such as various combinations of $\mathrm{Fe}, \mathrm{Co}, \mathrm{Ti}$ and $\mathrm{Ni}$ in ore concentrates, meteorites and archaeological artifacts can severely limit the detection of lower energy $\gamma$-rays owing to the self-absorption by the matrix.

\section{Result and Discussion}

The quality control of data obtained in this work was carried out by analyzing a Standard Reference Material (SRM) Fly ash 1633b as an unknown sample. Results of the analysis are then compared with the certified values of the standard as shown in Fig. 1.

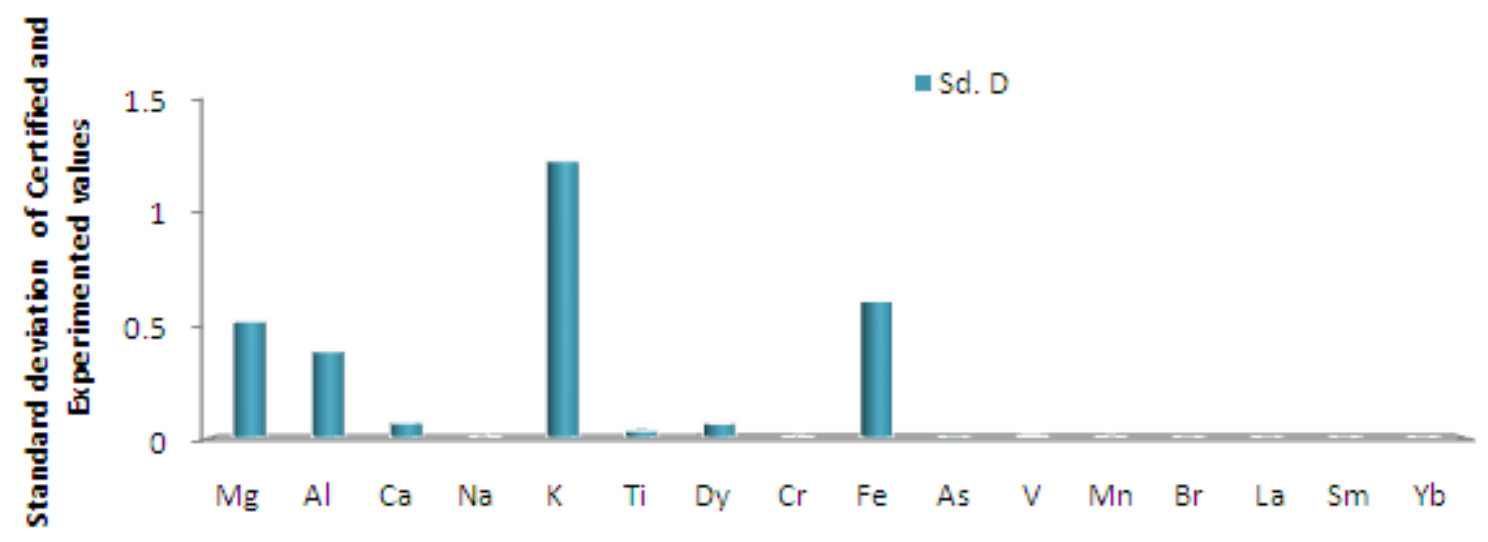

\section{Elemental concentrations in \%}

Figure 1: Comparison of certified values of Coal fly ash $1633 \mathrm{~b}$ with experimented values

Although instrumental neutron activation analysis has been developed into a dependable analytical tool, it is not without problems. Most of the time irradiated samples cause inconsistent thermalization of the thermal neutrons, which leads to variable elemental sensitivities. This problem may be responsible for biased results obtained in our reference materials for $\mathrm{K}( \pm 1.21 \%)$ and $\mathrm{Fe}( \pm 0.61 \%)$. However, the results for the other elements are in good agreement with their certified values (Fig. 1). This is an indication that the approach in this study of INAA is effective in the elimination of interfering nuclides and thereby allowing easy determination of micronutrient, macronutrients and heavy elements in the clay potteries.

The standard deviation obtained for $\mathrm{Mg}$ was $\pm 0.52 \%$ and the experimental value appeared to be three times higher than the certified values (Fig. 1). This is probably due to interference on magnesium $1014 \mathrm{keV}$ peak based on the $(\mathrm{n}, \gamma)$ nuclear reactions expressed as ${ }^{26} \mathrm{Mg}(\mathrm{n}, \gamma){ }^{27} \mathrm{Mg}$. There is an interference due to additional contribution arising from ${ }^{27} \mathrm{Al}$ in the sample due to the (n, p) nuclear reaction expressed as ${ }^{27} \mathrm{Al}(\mathrm{n}, \mathrm{p})$ ${ }^{27} \mathrm{Mg}$. This contribution from ${ }^{27} \mathrm{Al}$ could have been responsible for the discrepancy in the magnesium concentration. This error was corrected by measuring the reaction contribution from the $(n, p)$ due to ${ }^{27} \mathrm{Al}$ and subtracting the same from $(n, \gamma)$ reaction due to ${ }^{26} \mathrm{Mg}$. 
The results of the analysis of 10 composites clay potteries samples for both short and long-lived irradiation are presented below. The results of the irradiation of short-lived for the samples in the first and second $\gamma$-counting are shown in the following bar-charts for the different irradiation and counting scheme that were adopted during this work (Fig. 2 \& 3 ).

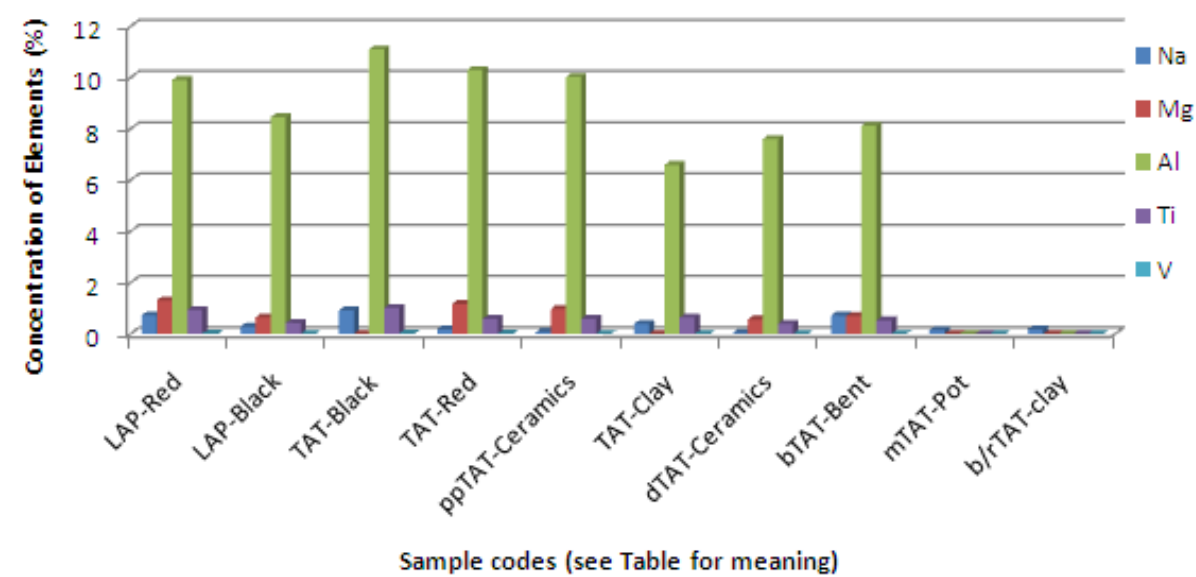

Fig. 2: The Elemental Concentration for first short-lived irradiation

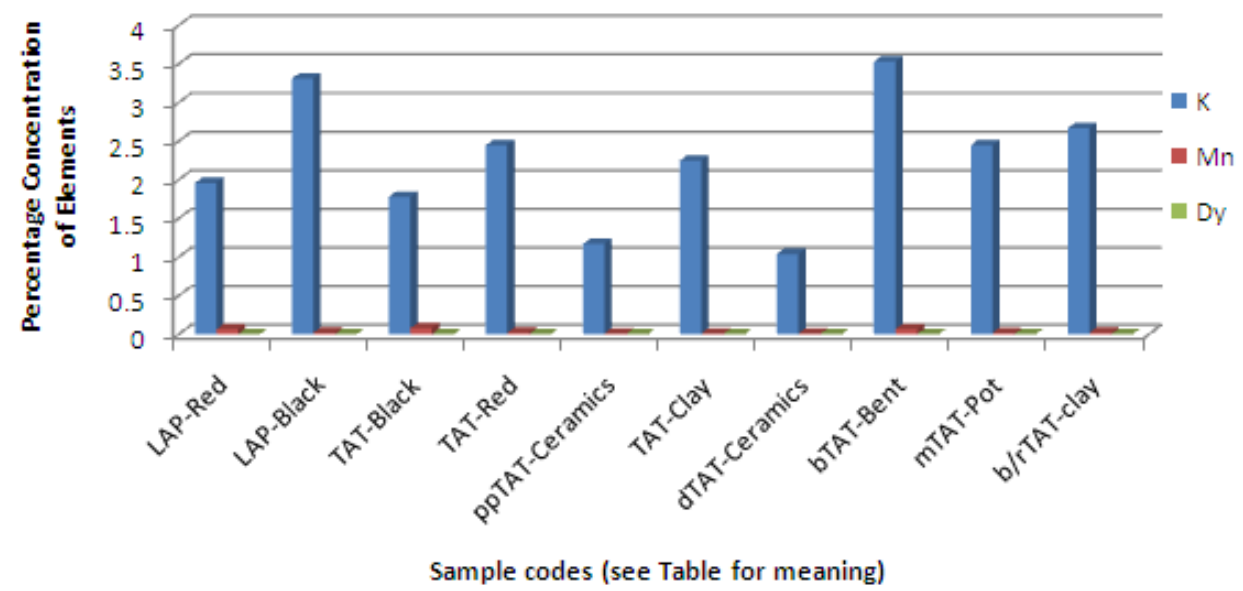

Fig. 3: Elemental Concentration for second short-lived irradiation

The results of long-lived radionuclides from the irradiated samples based on first and second $\gamma$ counting are shown in the Fig. 4 \& 5 respectively.

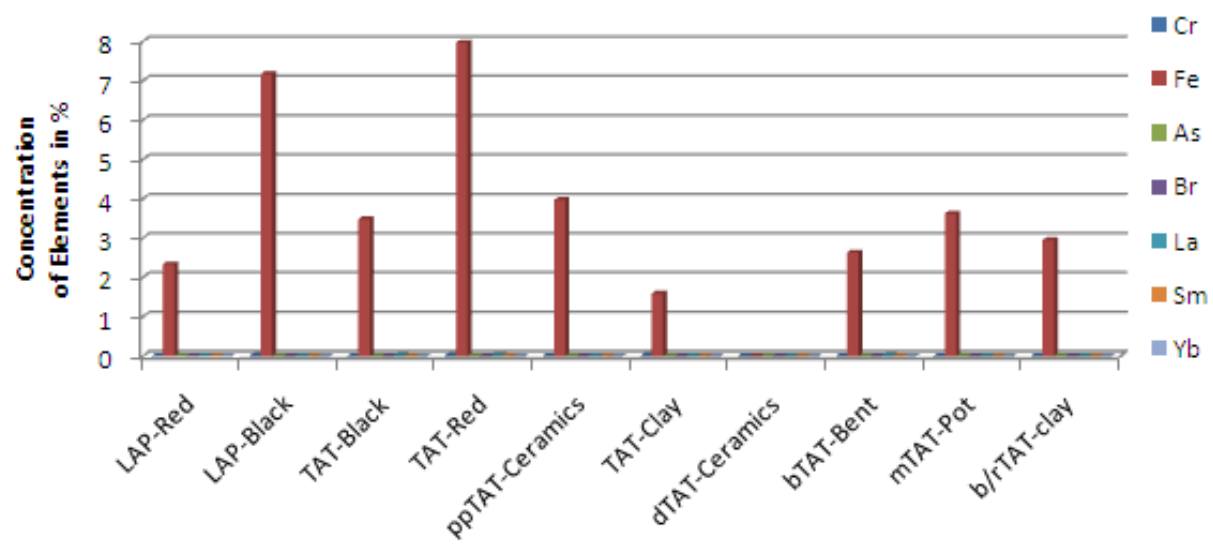

Sample codes (see Table for meaning)

Fig. 4: Elemental Concentration for first long-lived irradiation 


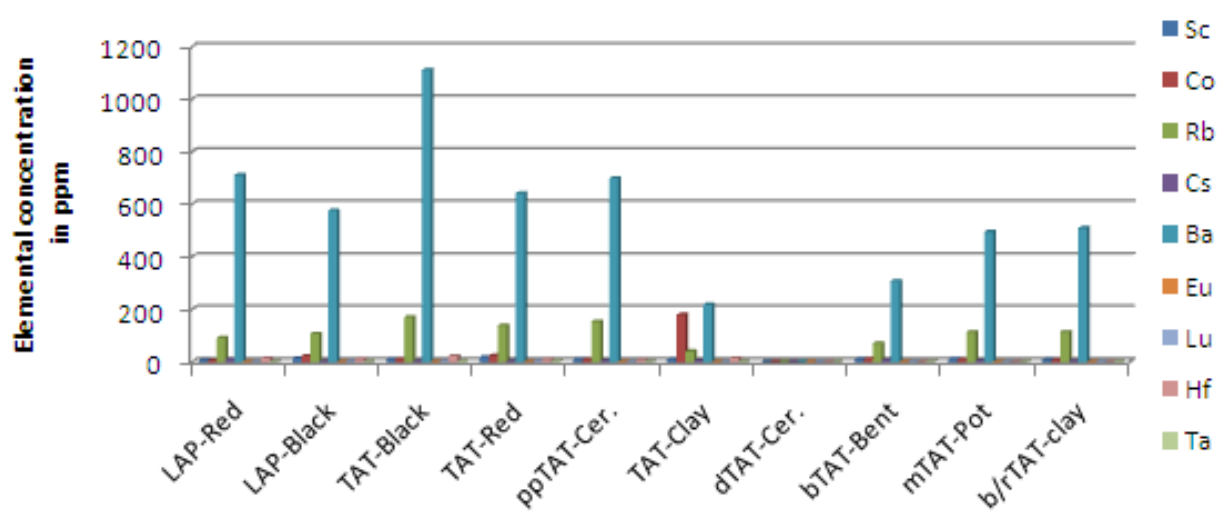

Sample codes (see Table for meaning)

Fig. 5: Elemental Concentration for second long-lived irradiation

However, the elemental concentrations of the elements obtained were further classified into the following categories namely; toxic elements (Fig. 6), essential and toxic metals (Fig. 7), and possibly required elements (Fig. 8).

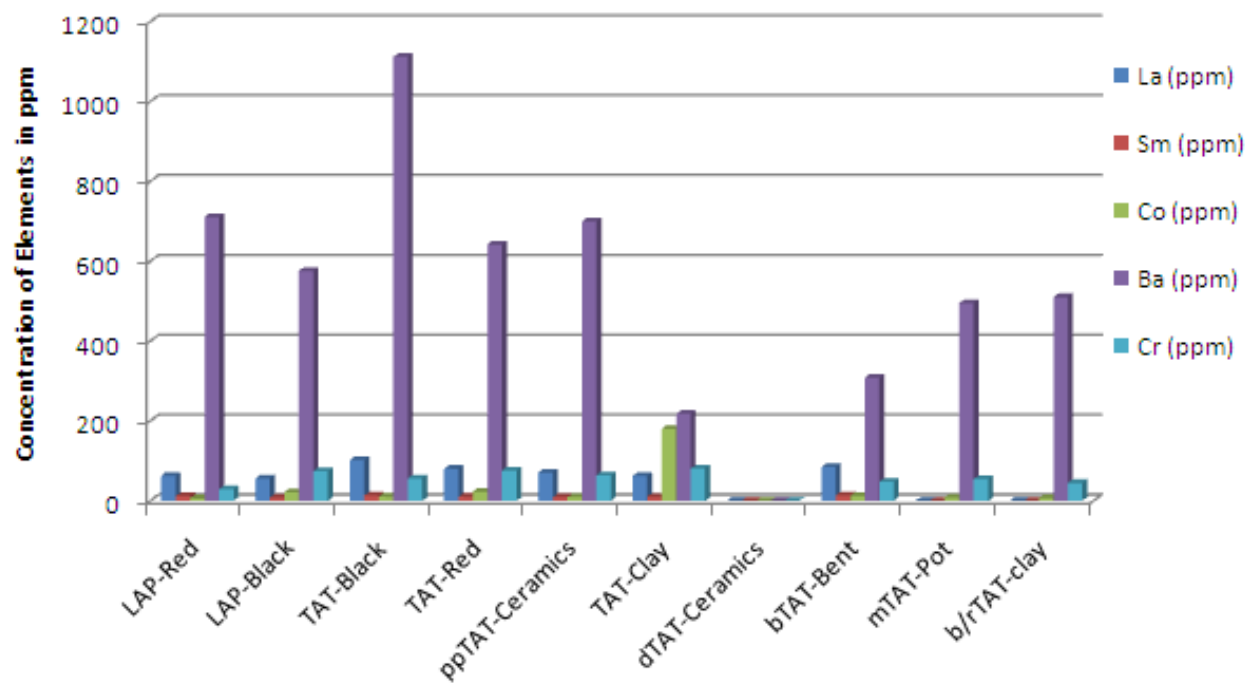

Sample's coded names (see Table 1.0 for meaning)

Fig. 6: Concentration of Toxic Elements obtained

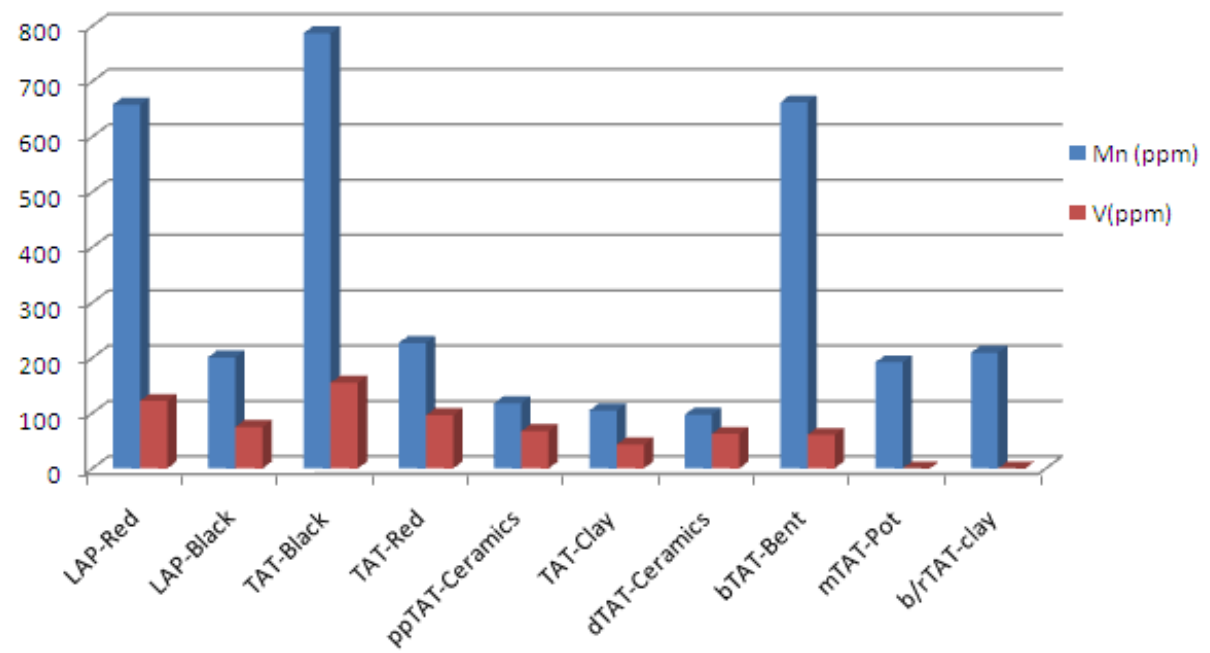

Fig. 7: Concentration of essential and toxic qualities 


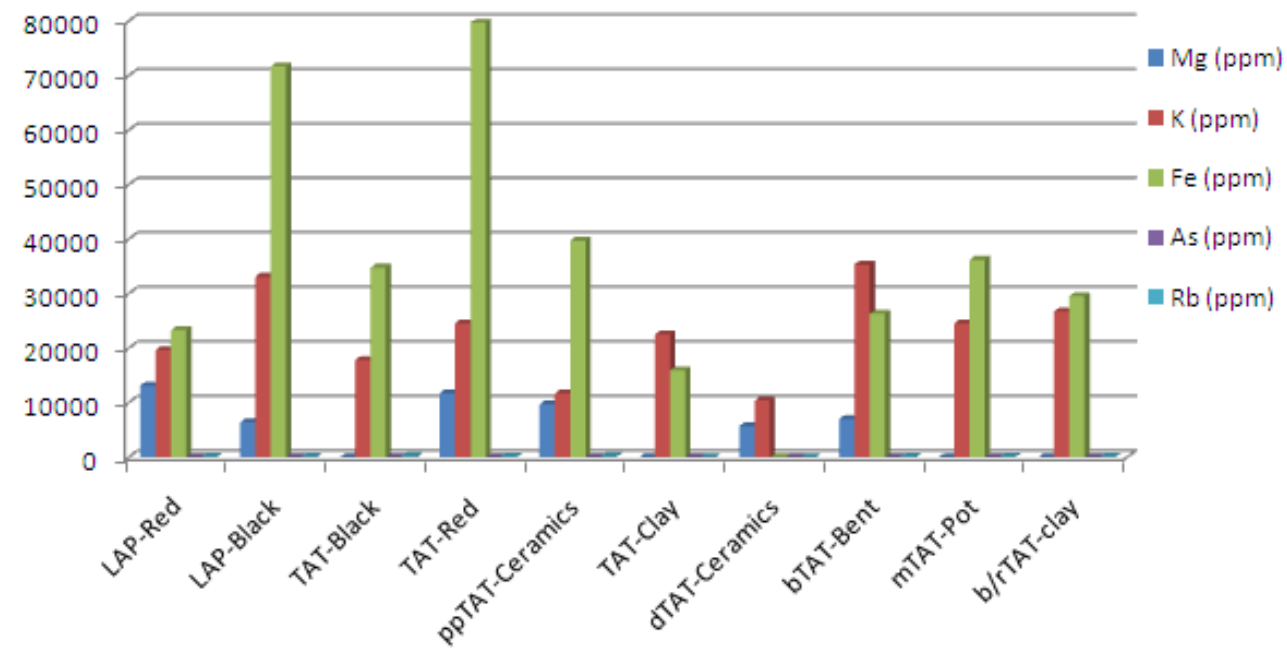

Fig. 8: Concentration of possibly requires elements

From samples analyzed, $\mathrm{Na}, \mathrm{Mg}, \mathrm{Al}, \mathrm{K}, \mathrm{Ti}$ and $\mathrm{Fe}$ were the major elements present at percentage level in the samples; LAP-Red, LAP-black, TAT-Black, TAT-Red, ppTAT-Ceramics, TAT-Clay, and bTAT-Bent; exception of dTAT-Ceramics (designed part of the Tatiko Ceramiscs) where Fe was below detection limit.

Al was found to be high at percentage levels (Fig. 2) in eight of the samples; LAP-Red, LAP-Black, TAT-Black, TAT-Red, ppTAT-Ceramics, TAT-Clay, dTAT-Ceramics, and bTAT-Bent. It recorded the maximum level in the TAT-Black (Tatiko clay type) found in Tatiko village. Al generally is called the soft in the head mineral because it is associated with memory loss and dementias. Beverages in $\mathrm{Al}$ cans or food cooked in clay potteries containing these elevated levels of $\mathrm{Al}(7.605 \pm 0.006-10.0350 \pm 0.026 \%)$ and $\mathrm{Ti}(0.40 \pm 0.03$ $1.02 \pm 0.07 \%$ ) as shown in Fig. 2 posed serious dangers to the human health especially as these elements may can come off onto the food during drinking, cooking or eating.

Other elements which were detected in ppm were; V, Mn, Eu, Dy, Cr, As, Br, La, Sm, Yb, Sc, Co, Rb, $\mathrm{Cs}, \mathrm{Ba}, \mathrm{Lu}, \mathrm{Hf}$ and Ta. According to the toxicological studies (U.S. Environmental Protection Agency, 1994) an amount of $2.00 \mathrm{ppm}$ used in rat actually poisoned it and in a moderate to large concentrations can cause death while smaller concentrations caused damage to the heart, blood vessels, and nerves.

It was observed that LAP-Red (Lapai-red clay) had the highest percentage of $\mathrm{Na}, \mathrm{Mg}$ and $\mathrm{Ti}$ (Fig. 2 \& 8). However, $\mathrm{Mg}$ was not detected in both TAT-Black and TAT-Clay. $\mathrm{Mn}, \mathrm{Rb}$ and Ba were present in large amount in nine composite samples; TAT-Black was rich in $\mathrm{La}, \mathrm{Ba}$ and $\mathrm{Rb}$ in comparison with the other seven composite samples. Also shown in Fig. $4 \&$ 8, As was only detected in four of the composite samples at trace levels. No known necessary role of As in human or animal diet has been acknowledged yet, but it is toxic. As is cumulative poison that is slowly excreted and can cause nasal ulcers; damage to the kidneys, liver, and intestinal walls; and death. Recently As was suspected to be carcinogen (U.S. Environmental Protection Agency, 1994).

The designed part of Tatiko ceramics (dTAT-Ceramics) was analyzed with only nine elements out of the twenty four elements obtained. The remaining elements ( $\mathrm{Cr}, \mathrm{Fe}, \mathrm{As}, \mathrm{Br}, \mathrm{La}, \mathrm{Sm}, \mathrm{Yb}, \mathrm{Sc}, \mathrm{Co}, \mathrm{Rb}, \mathrm{Cs}, \mathrm{Ba}, \mathrm{Lu}, \mathrm{Hf}$ and Ta) were below detection limit. Tatiko clay deposit (TAT-clay) was noted to have high amount of Co compare to the other samples (Fig. 5). The concentration ranges of Sm obtained in all the samples were from $9.64 \pm 0.23$ to $13.10 \pm 0.53 \mathrm{ppm}$. This is very low to cause any health problems (Evaluation of certain food additives and contaminants, $33^{\text {rd }}$ Report of the Joint FAO/WHO Expert Committee ON Food Additives, WHO Technical Report Series, Number 776, Geneva, Switzerland).

The mixture of Tatiko black and red clay (b/rTAT-clay) and the Tatiko finished product of the mixed clay (mTAT-Pot) respectively showed; $\mathrm{Na}(0.72 \pm 0.02$ and $0.18 \pm 0.051 \%), \mathrm{K}(2.45 \pm 0.023$ and $2.67 \pm 0.013$ $\%)$ and $\mathrm{Fe}(03.62 \pm 0.021$ and $2.95 \pm 0.023 \%)$ as shown in Fig. $2 \& 8$. These were the major elements present at percentage levels while other elements like; $\mathrm{Mn}, \mathrm{Eu}, \mathrm{Dy}, \mathrm{Sc}, \mathrm{Cr}, \mathrm{Co}, \mathrm{Rb}, \mathrm{Cs}, \mathrm{Ba}, \mathrm{Yb}, \mathrm{Lu}, \mathrm{Hf}, \mathrm{Ta}$ were present at ppm levels. It was seen that $\mathrm{Mn}$ was lowest in the clay materials of $105.00 \pm 28 \mathrm{ppm}$ (TAT-Clay) as compared to the finished products of the mixed clay of about $192.00 \mathrm{ppm}$ (mTAT-Pot) as shown in Fig. 7. This effect could be attributed to the firing and furnishing process, thereby losing some quantities. Almost all the elements detected increased in the finished product which could be attributed to either impurities or the oxides used in the designed.

The clay pottries from Lapai and Tatiko villages recorded high Mn $(97.30 \pm 21-787.0 \pm 51 \mathrm{ppm})$ and As $(0.88 \pm 0.12$ to $1.63 \pm 0.25 \mathrm{ppm})$ known as trace elements. The value of As obtained is far above the permissible value of $0.05 \mathrm{ppm}$ of the U.S. Environmental Protection Agency (1994). It was reported by Ostergaad (1977) that some cigarettes can contain between 0.9 and $2.0 \mathrm{ppm}$ (dry weight) and in another 
publication (Nwankwo et al., 1977) that every 20 cigarettes smoked contributes $0.5-2.0 \mu \mathrm{g}$ of the metal (As) to the body through the lungs. There is growing evidence that As may play a metabolic role, possibly as an activator of certain enzymes (Uthus et al., 1989). Prior to the understanding of its toxicity, As was used in medicine, for example in the treatment of skin problems and prevention of leukemia and anemia (Fierz, 1965), and recently in Ayurvedic medicine (Kew et al., 1993). It has been argued that As is an essential nutrient for humans (Nielsen, 1990). Arsenic (As) deprivation in farm animals has been associated with depressed growth and abnormal reproduction (Anke et al., 1991).

On the other hand, it has been reported that absorption of Fe is influenced by body stores (Bothwell et al., 1979; Cook et al., 1974), by the amount and chemical nature of $\mathrm{Fe}$ in the ingested food as fallout from clay potteries and by a variety of dietary factors that increase or decrease the availability of Fe for absorption (Gillooly et al., 1983; Hambidge et al., 1986). Supplementation to a total Fe intake much above the recommended dietary allowance (NRC, 1989) is therefore discouraged.

The required trace minerals include; $\mathrm{Mg}, \mathrm{Cr}, \mathrm{V}$ and $\mathrm{Co}$ which were obtained in the clay potteries samples at relatively small quantities are summarized as shown in Fig. 4, 6, $7 \& 8$. The possibly required trace minerals include; As, $\mathrm{Rb}, \mathrm{Fe}, \mathrm{K}$ and $\mathrm{Mg}$ that were obtained in this work as shown in Fig. 2, 3, 4, 5 \& 8 . However, $\mathrm{Mg}, \mathrm{K}$, and $\mathrm{Fe}$ were obtained at percentage levels while As and $\mathrm{Rb}$ obtained at ppm levels. $\mathrm{Rb}$ was obtained in large quantities in all the samples except the dTAT-Ceramics as shown in Fig. 5. Among the potentially toxic elements (PTEs): $\mathrm{As}, \mathrm{Ca}, \mathrm{Cr}, \mathrm{Cu}, \mathrm{Pb}, \mathrm{Hg}$, Ni and $\mathrm{Zn}$, we obtained the following elements; As and $\mathrm{Cr}$ in the clay potteries sample types at trace levels as shown in Fig. 4, $6 \& 8$.

The $\mathrm{Cr}$ concentration range was observed to be in the range of $29.20 \pm 23-80.80 \pm 21 \mathrm{ppm}$ (Table 6). TAT-Clay (Tatiko clay deposit) had the highest concentration, with $80.80 \pm 21 \mathrm{ppm}$ followed by TAT-Red (Tatiko red clay) at $75.40 \pm 33 \mathrm{ppm}$. These are very concentrations compared to the $0.05 \mathrm{ppm}$ limit of U.S. Environmental Protection Agency (1994), and as thus pose threat to human health.

Background concentrations of heavy metals in the clay soils are known to have stemmed from the soil parent material such as rocks and sediments (U.S. Environmental Protection Agency, 1994). These categories of required trace element, possibly required trace elements and toxic elements often overlap slightly because assessing elements that are required by humans is problematic. Some may be needed in minuscule amounts. Clinical studies to prove this by depriving people of vital minerals would be cruel and possibly disastrous.

In clinical experience, everyone has excessive amounts of some or all of the toxic metals. Toxic metals $\mathrm{La}(56.20 \pm 21-102.00 \pm 43 \mathrm{ppm}), \mathrm{Sm}(8.14 \pm 0.32-13.10 \pm 0.2 \mathrm{ppm}), \mathrm{Co}(6.22 \pm 0.22-21.50 \pm 0.26$ ppm), $\mathrm{Ba}(218.00 \pm 28$ to $711.00 \pm 41 \mathrm{ppm})$, and $\mathrm{Cr}(29.20 \pm 23-80.80 \pm 21 \mathrm{ppm})$, were obtained in this work (Fig. 6) and are also persistent and cumulative. The International Agency for Research on Cancer (IARC) (Kanias et al., 1993) has listed Co and Co compounds within group 2B (agents which are possibly carcinogenic to humans). The Federal Republic of Germany has also classified Co to be carcinogenic to experimental animals. This element was found in all the samples in the range $6.22 \pm 0.22-21.50 \pm 0.26$ ppm as shown in Fig. $5 \& 6$ with TAT-Clay recording the highest and LAP-red clay the lowest.

Generally toxic metals replace nutrient minerals in enzyme binding sites. When this occurs, the metals inhibit, over stimulate or otherwise alter thousands of enzymes. An affected enzyme may operate at $5 \%$ of normal activity. This may contribute to several health conditions. Toxic metals may also replace other substances in other tissue structures. These tissues, such as the arteries, joints, bones and muscles, are weakened by the replacement process. Toxic metals may also simply deposit in many sites, causing local irritation and other toxic effects. They may also support development of fungal, bacterial and viral infections that are difficult or impossible to eradicate until this cause is removed in clay potteries (Eck and Wilson 1989).

\section{Conclusion}

This work basically provide a baseline data to list out the elements present and percentage concentrations in terms of trace elements, possibly required, essential and toxic, human health risk quality. From the analytical results of the ten composite geological samples using CERT (Centre for Energy Research and Training, Ahmadu Bello University, Zaria) facility, it was deduced that Instrumental Neutron Activation Analysis (INAA) has proved to be an effective method of analyzing trace elements in clay and pottery wares. The basic major elements present universally in clay materials are clearly identified at percentage and ppm concentrations. The technique was found to be reliable and efficient when compared the experimental values obtained to the National Institute of Standard and Technology (NIST) coal fly ash 1633b. The toxic elements obtained were; La (56.20 to $102.00 \mathrm{ppm}), \mathrm{Sm}(8.14 \pm 0.32-13.10 \pm 0.2 \mathrm{ppm})$, Co (6.22 $\pm 0.22-21.50 \pm 0.26 \mathrm{ppm}), \mathrm{Ba}(218.00 \pm$ 28 to $1112.00 \pm 41 \mathrm{ppm})$ and $\mathrm{Cr}(29.20 \pm 23-80.80 \pm 21 \mathrm{ppm})$. These values posed serious health risk and public awareness must be created. 


\section{References}

[1]. Abugassa, I. O., Sarmani, S., and El-Ghawi, U., (2004) "Instrumental neutron activation analysis based on k0-standardization method as compared with other methods in the analysis of the IAEA inter-comparison test," Journal of Radioanalytical and Nuclear Chemistry, vol. 259, no. 3, pp. 381-384.

[2]. Ahlrichs, J. L., (1972) "The soil environment," in Organic Chemicals in the Soil Environment, C. A. I. Goring and J.W. Hamaker, Eds., Marcel Dekker, New York, NY, USA.

[3]. Ahmed, Y.A., Ewa, I.O.B., Umar, I.M. 2006. Variations in nuclear data and its impact on INAA. Journal of Applied Sciences, 6(8), 1692-1697.

[4]. Ames, BN, Elson-Schwab, I., Silver, EA, (2002). High-dose vitamin therapy stimulates variant enzymes with decreased coenzyme binding affinity: relevance to genetic disease and polymorphisms, Am J Clin Nut.,75(4):616-658.

[5]. Anderson, M. and Jensen, B. (1993). Empty Harvest; Understanding the Link Between Our Food, Our Immunity and Our Planet, Avery Penguin Putnam.

[6]. Anke, M., B. Groppel, U. Krause, 1991. The essentiality of the toxic elements cadmium, arsenic and nickel. In: Trace elements in man and animals-7(ed. B. Momcilovic), pp. 11/6-11/8. Institute for Medical Research and Occupational Health, Zagreb, Croatia.

[7]. Bauer, B., (1999), The Early Ceramics of the Inca Heartland, Fieldiana_No. 31, Field Museum of Natural History.

[8]. Bothwell, T.M., R.W. Charlton, J.D. Cook, C.A. Finch, 1979. Iron, metabolism in man, Blackwell, Oxford.

[9]. Brooks, D., Rogers, M. S., Mitchell, R. S and Hoffman, M. A. (1982): A geochemical approach to the understanding of ceramic technology in predynastic Egypt.

[10]. Carlisle, E.M., 1986. Silicon. in W. Mertz, ed. Trace Elements in human and Animal Nutrition. Academic Press, New York, 5th ed., 2, 373-390.

[11]. Casdorph, H.R. and Walker, M., (1995). Toxic Metal Syndrome, Avery Publishing, NY.

[12]. Cook, J.D., D.A. Lipschitz, L.E.M. Miles, C.A. Finch, (1974). Serum ferritin as a measure of iron stores in normal subjects, Am. J. Clin. Nutr. 27: 681-687.

[13]. De Soete, D., Gijbels, R., and Hoste, J., (1972). Neutron Activation Analysis, JohnWiley \& Sons, London, UK.

[14]. Eck, P. and Wilson, L., (1989). Toxic Metals in Human Health and Disease, Eck Institute of Applied Nutrition and Bioenergetics, Ltd., AZ, p. 14.

[15]. Environmental Protection Agency, Research and Development (1994), Toxic Trace Metals in Human and Mammalian Hair, EPA600, 4.79-049, August, p. 3.

[16]. Ewa, I. O. B., Oladipo, M. O. A., Dim, L. A., and Mallam, S. P., (2000) "Major, minor and trace elements of the Samaru savannah soil in Nigeria," Journal of Trace and Microprobe Techniques, vol. 18, no. 3, pp. 389-395.

[17]. Funtua I. I., Oladipo M.O.A., Njinga R. L., Jonah S.A., Yusuf I. and Ahmed Y.A, (2012). Evaluation for Accuracy and Applicability of Instrumental Neutron Activation Analysis of Geological Materials on Nigeria Nuclear Research Reactor-1(NIRR-1). International Journal of Applied Science and Technology Vol. 2 No. 1.

[18]. Gharib, A.G. (2004). New trace elements in Iranian diets, J. Radioanal. Nucl. Chem., 262 (1), $199-204$.

[19]. Gillooly, M., T.H. Bothwell, J.D. Torrence, A.P. Mac Phail, D.P. Derman, W.R. Bezwoda, W. Mills, R.W. Charlton, (1983). The effects of organic acids, phytates, and polyphenols on the absorption of iron from vegetables, Br. J. Nutr. 49:331-342.

[20]. Greger, J.L. (1989). Potential for trace mineral deficiencies and toxicities in the elderly. in C. W. Bales, eds. Mineral Homeostasis in the elderly. Current topics in Nutrition and Disease, Alan R. Liss, New York. Vol. 21 pp 171-200.

[21]. Hambidge, K.M., C.E. Casey, N.F. Krebs, (1986). Zinc. In W. Mertz, ed. Trace Elements in Human and Animal Nutrition, Academic Press New York, 5th ed. 1, 1-137.

[22]. Hurley, J.S. and Keen, C.L., (1987). Manganese. In: W. Mertz ed. Trace Elements in Human and Animal Nutrition, , Academic Press, New York, 5th ed. 1, 185-223.

[23]. Kanias, G.D., Kilikoglou, V., Tsitsa, E., Loukis, A., (1993). Determination and statistical analysis of trace element and active constituent concentrations in the medicinal plant Eucalyptus Camaldulensis Deehnh (E. Rostratus schlecht). J.

[24]. Kaplan, M. F., Harbottle,G. and Sayre, E. V. (1982): Multidisciplinary analysis of Tell el Yahudiyeh ware. Archaeometry 24, 127142.

[25]. Kay, R. E., Stevens-Gullie, P. D., Hillborn, J. W and Jervis, R. E. (1973): SLOWPOKE: a new low-cost laboratory reactor. International Journal of Applied Radiation and Isotopes, 211, 111-115

[26]. Kew, J., C. Morris, Aihie, A., R. Fysh, S. Jones, D. Brooks, (1993). Arsenic and mercury intoxication due to Indian ethnic remedies. British Medical Journal, 306: 506-507.

[27]. Landsberger, S., S. Larson, D. Wu, (1993). Determination of airborne cadmium in environmental tobacco smoke by instrumental neutron activation analysis with a Compton suppression system, Analytical Chemistry, 65 (11), 1506-1509.

[28]. Lee, C., and Kwun, C. (1985): Neutron Activation Analysis of Korean clays and Pottery, Seoul, Korea.(Humana Press, New Jersy)

[29]. Liyu, W., WINSPAN (2004), A Multi-Purpose Gamma-Ray Spectrum Analysis Software, CIAE, Beijing, China, 2004.

[30]. Menaut, J. C., Barbault, R., Lavelle, P., and Lepage, M., (1985) "African Savannas: biological systems of humification and mineralization," in Ecology and Management of theWorld's Savannas, J. C. Tothill and J. J. Mott, Eds., pp. 14-33, Australian Academic Science, Canberra, Australia.

[31]. Mosugu, M. E., Chude, V. O., Esu, I. E., Kparmwang, T., and Malgwi, W. B. (1999) "Contents and profile distribution of three forms of free iron oxides in three ultisols and an Alfisol in Nigeria," Communications in Soil Science and Plant Analysis, vol. 30, no. 7-8, pp. 1013-1024.

[32]. Muir, M., (1997). Current controversies in the diagnosis and treatment of heavy metal toxicity, Alternative and Comp Ther.,170178 .

[33]. Nielsen, F.H., (1990). Other trace elements. In: Present Knowledge in Nutrition (ed. M.L. Brown), International Life Sciences Institute, Washington, DC. pp. 294-307.

[34]. Njinga R.L, Baba Alfa., Okoh Sunday and Muhammad T. A, (2011a). Evaluation of trace elements in clay sediments products of Tatiko locality using x-ray fluorescence technique. Advances in Applied Science Research, 2 (6):370-378

[35]. Njinga, R. L., Jonah, S. A., Ewa, I. O. B., Oladipo, M. O. A., and Agbo, G. A., (2011b) "Alternative approach for efficiency data generation in neutron activation analysis," International Journal of Applied Science and Technology, vol. 1, no. 5, pp. 244-256.

[36]. Njinga R.L., Jonah S.A., Oladipo M.O.A., Ewa I.O.B., Alfa B. (2012). Comparator Factors for Single Standardization Techniques in Elemental Analysis of Archaeological Matrices. Journal of Science and Technology Volume 1 No. 7.

[37]. NRC (National Research Council) (1989). Recommended Dietary Allowance, 10th Ed., Food and Nutrition Board, National Academy Press, Washington, USA. 
[38]. Nwankwo, J.N., C.G. Elinder, M. Piscator, B. Lind, (1977). Cadmium in Zambian cigarettes: an inter-laboratory comparison in analysis. Zambian Journal of Science and Technology, 2: 1-4.

[39]. Oladipo, M.O.A., (1992): Neutron Activation Analysis of Clay and their Classification for mineral prospecting. Centre for Energy Research and Training CERT, Zaria.

[40]. Ostergaad, K., (1977). Cadmium in cigarettes. Acta Medica Scandinavica, 202:193-197.

[41]. Perlman, I. and Asaro, F. (1971): Pottery analysis by neutron activation. (Cambridge, London).

[42]. Requirements of vitamin A, iron, folate and vitamin B12. Report of a Joint FAO/IAEA/WHO Expert Consultation. Rome, Food and Agriculture Organization of the United Nations, (1988) (FAO Food and Nutrition Series, no. 23).

[43]. Tobia, S.K. and Sayre, E. V (1974): An analytical comparison of various Egyptian soils, clays, shales and some ancient pottery by neutron activation, (Plenum Press, New York).

[44]. Tolgyessy, J., and Klehr, E. H., (1987). Nuclear Environmental Chemical Analysis, Series in Analytical Chemistry, EllisHorwood, Chichester, UK.

[45]. Uthus, E.O., R. Poellot, B. Brossart, F.H. Nielsen, (1989). Effect of arsenic deprivation on polyamine content in rat liver. Federation of American Societies of Experimental Biology Journal, Vol. 3, A1072.

[46]. World Health Organization (WHO), (1989). Evaluation of certain food additives and contaminants, 33rd Report of the Joint FAO/WHO Expert Committee on Food Additives, WHO Technical Report Series, Number 776. Geneva, Switzerland. 